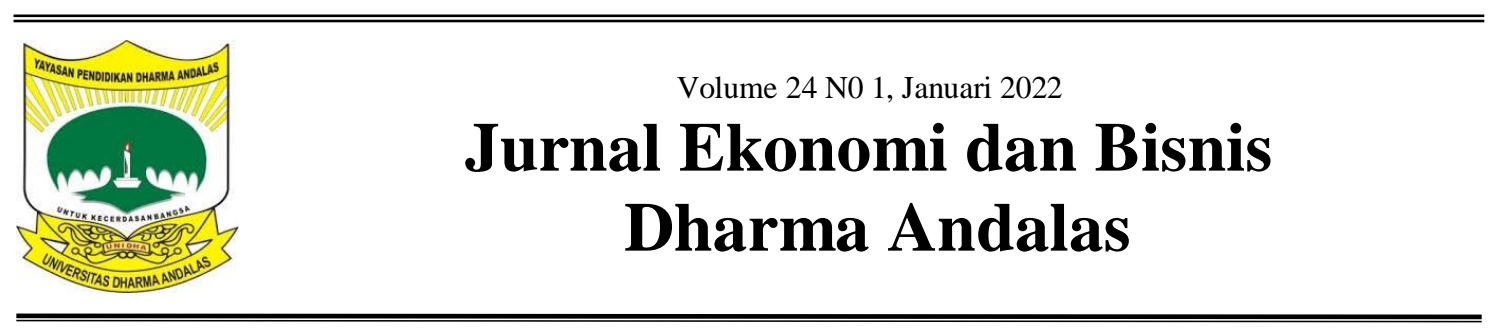

\title{
Trend Penghindaran Pajak Pada Perusahaan Makanan dan Minuman Yang Terdaftar di Bursa Efek Indonesia
}

\author{
Yunita Valentina Kusufiyah ${ }^{1}$, Dina Anggraini ${ }^{2}$ \\ Fakultas Ekonomi dan Bisnis Universitas Dharma Andalas ${ }^{1,2}$ \\ e-mail:yunitavalentina@unidha.ac.id \\ dnariyna@yahoo.com
}

\begin{abstract}
Tax avoidance is an action taken by taxpayers to reduce the tax burden by exploiting the weakness of legislation (loopholes), although this tax avoidance practice does not violate the laws and regulations but this action is considered an immoral act (unacceptable). This research is motivated by the large number of tax evasion carried out by corporations which has become a complaint in several countries, including Indonesia, which causes state losses. This study uses the Effective Tax Ratio (ETR) as a proxy or measurement of tax avoidance. The ETR method is done by dividing income tax expense by profit before tax. This study aims to empirically test the avoidance trend in food and beverage companies listed on the Indonesia Stock Exchange. This type of research is descriptive research, namely research that explains one variable in a particular situation. The population in this study are food and beverage companies listed on the Indonesia Stock Exchange (IDX) in 2011-2020 with a population of 80 companies. This study found the average value of ETR within 10 years was $23 \%$ and the maximum value of ETR for 10 years (2011-2020) was 34.87\%, namely in 2015.
\end{abstract}

Keyword: tax avoidance, effective tax rates, tax amnesty, debt to equity ratio

\section{ABSTRAK}

Penghindaran pajak merupakan tindakan yang dilakukan oleh wajib pajak untuk mengurangi beban pajak dengan memanfaatkan kelemahan peraturan perundang-undangan (loopholes), meskipun praktek penghindaran pajak ini tidak melanggar peraturan perundang-undangan tetapi tindakan ini dianggap sebagai perbuatan tidak bermoral (unacceptable). Penelitian ini termotivasi dari banyaknya penghindaran pajak yang dilakukan oleh korporasi yang menjadi keluhan beberapa negara termasuk di Indonesia yang menimbulkan kerugian negara. Penelitian ini menggunakan Effective Tax Ratio (ETR) sebagai proksi atau pengukuran penghindaran pajak. Metode ETR ini dilakukan dengan membagi beban pajak penghasilan dengan laba sebelum pajak. Peneltian ini bertujuan menguji secara empiris tentang trend penghindaran pada perusahaan makanan dan minuman yang terdaftar pada Bursa Efek Indonesia. Jenis penelitian ini adalah penelitian deskriptif, yaitu penelitian yang menjelaskan satu variable dalam situasi tertentu. Populasi dalam penelitian ini adalah perusahaan makanan dan minuman yang terdaftar di Bursa Efek Indonesia (BEI) tahun 20211-2020 dengan populasi sebanyak 80 perusahaan. Penelitian ini menemukan nilai rata-rata ETR dalam kurun waktu 10 tahun sebesar 23\% dan nilai maksimal ETR sepanjang 10 tahun (2011-2020) sebesar 34,87\% yaitu pada tahun 2015.

Keyword: penghindaran pajak, effective tax rates, tax amnesty, debt to equity ratio 


\section{PENDAHULUAN}

Pajak merupakan sumber penerimaan negara Indonesia yang terbesar, untuk itu pemerintah melakukan banyak upaya dalam meningkatkan tingkat kepatuhan wajib pajak di Indonesia. Upaya pemerintah dalam meningkatkan kepatuhan wajib pajak di Indonesia tentunya tidak terlepas dari berbagai hambatan, salah satunya adalah praktek penghindaran pajak (tax avoidance) yang dilakukan oleh wajib pajak. Pada tahun 2020 Tax justice network menemukan kerugian negara Indonesia mencapai hampir sebesar 68,7 triliun rupiah per tahun yang diakibatkan oleh penghindaran pajak baik wajib pajak korporasi maupun wajib pajak orang pribadi (Santoso, 2020). Penghindaran pajak merupakan tindakan yang dilakukan oleh wajib pajak untuk mengurangi beban pajak dengan memanfaatkan kelemahan peraturan perundang-undangan (loopholes), meskipun praktek penghindaran pajak ini tidak melanggar peraturan perundangundangan tetapi tindakan ini dianggap sebagai perbuatan tidak bermoral (unacceptable). Menurut (Darussalam \& Septriadi, 2008) praktek penghindaran pajak dapat dilakukan dalam beberapa bentuk antara lain : subtantive tax planning dan formal tax planning. Subtantive tax planning dilakukan dengan memindahkan pajak ke negara yang memberikan perlakukan khusus atas suatu jenis penghasilan, memindahkan objek ke negara yang dikategorikan sebagai negara yang memberikan perlakukan pajak khusus atas suatu jenis penghasilan dan memindahkan subjek pajak serta objek pajak ke negara yang dikategorikan memberikan perlakuan khusus atas suatu jenis penghasilan. Formal tax planning merupakan penghindaran pajak dengan cara tetap mempertahankan subtansi ekonomi dari suatu transaksi dengan memilih berbagai bentuk formal jenis transaksi yang memberikan beban pajak lebih rendah.

Penelitian ini termotivasi dari banyaknya penghindaran pajak yang dilakukan oleh korporasi yang menjadi keluhan beberapa negara termasuk di Indonesia yang menimbulkan kerugian negara. Kasus penghindaran pajak di Indonesia yang dilakukan oleh korporasi telah banyak terjadi, salah satunya penghindaran pajak yang dilakukan oleh PT. Coca Cola Indonesia tahun pajak 2002, 2003, 2004, dan 2006. Direktorat Jenderal Pajak dalam kasus ini menemukan adanya pembekakan biaya yang besar sehingga menyebabkan penghasilan kena pajak berkurang dan setoran pajak pun menjadi lebih kecil, hal ini menimbulkan kekurangan pajak penghasilan PT. Coca Cola Indonesia sebesar 29,24 milyar rupiah. Direktorat Jenderal Pajak dalam kasus ini mengindikasikan bahwa PT. Coca Cola telah melakukan transfer pricing guna untuk penghindaran pajak.

Penghindaran pajak melalui tindakan Transfer pricing jika penentuan harga dalam transaksi antar pihak dipengaruhi oleh hubungan istimewa dan dilakukan tidak sesuai dengan ketentuan perpajakan. Praktek penghindaran pajak melalui transfer pricing biasanya dilakukan oleh perusahaan-perusahaan multinasional termasuk didalamnya adalah perusahaan manufaktur yang banyak memiliki anak perusahaan baik didalam negeri maupun diluar negeri sehingga lebih rentan untuk melakukan transfer pricing, dalam hal ini salah satunya adalah perusahaan sub sektor makanan dan minuman. Perusahaan sub sektor ini cendrung lebih banyak memiliki anak perusahaan dari sub sektor lainnya.

Tujuan penelitian ini berdasarkan fenomena penghindaran pajak diatas adalah untuk mengetahui tren penghindaran pajak pada perusahaan 
khususya pada perusahaan sektor makanan dan minuman yang terdaftar di BEI dan dengan mengetahui trend penghindaran pajak ini diharapkan dapat berguna untuk membuat peramalan yang diperlukan oleh Direktorat Jenderal Pajak dalam mengambil kebijakan terkait penghindaran pajak. Penelitian ini menggunakan Effective Tax Ratio (ETR) sebagai proksi atau pengukuran penghindaran pajak. Metode ETR ini dilakukan dengan membagi beban pajak penghasilan dengan laba sebelum pajak. Penggunaan metode ETR dalam penelitian ini diharapkan dapat memberikan gambaran secara menyeluruh terkait beban pajak yang akan berdampak pada laba akuntansi. Penggunaan ETR sebagai pengukuran penghindaran pajak telah dilakukan oleh beberapa peneliti seperti (Dyreng et al., 2008). Nilai ETR yang rendah mencerminkan jumlah pajak yang dibayarkan oleh perusahaan kecil hal ini terjadi dikarenakan adanya kecendreungan perusahan yang mengecilkan laba kena pajak mereka sehingga dapat berdampak terhadap kecilnya jumlah pajak yang dibayarkan. Penelitian ini menggunakan data laporan keuangan perusahaan sektor makanan dan minuman dalam kurun waktu 10 tahun dari tahun 2011 sampai dengan tahun 2020. Rentang waktu yang panjang dalam penelitian ini diharapkan dapat mengamati dan memperoleh gambaran tentang perusahaan khususnya perusahaan sektor makanan dan minuman yang melakukan penghindaran pajak. Trend penghindaran pajak ini juga akan berguna bagi Direktorat Jenderal Pajak dalam melakukan pengawasan dan mengevalusi kebijakan yang akan dikeluarkan terkait dengan peningkatan kepatuhan wajib pajak. Penelitian ini bertujuan untuk menguji secara empiris guna mengetahui dan menganalisis trend penghindaran pajak pada perusahaan
Makanan dan Minuman yang terdaftar di Bursa Efek Indonesia.

Urgensi penelitian ini dilakukan karena penghindaran pajak merupakan tindakan dan usaha wajib pajak untuk mengurangi jumlah pajak yang dibayar dengan memanfaatkan kelemahan undang-undang perpajakan (loopholes), meskipun tindakan ini tidak melanggar undang-undang tetapi praktek penghindaran pajak dianggap tindakan yang tidak bermoral dikarena wajib pajak berusahaan untuk mengurangi jumlah pajak yang akan dibayarkan kepada negara. Praktek penghindaran pajak tentunya akan mengurangi potensi penerimaan negera dari pajak dan hal ini merupakan salah satu wujud ketidakpatuhan wajib pajak sehingga program pemerintah untuk menyejahterakan rakyat tidak dapat tercapai dan hal ini merupakan tindakan yang akan merugikan rakyat. Pemerintah melalui Direktorat Jenderal Pajak dalam meningkatkan dan memperbaharui kebijakan bidang perpajakan menempatkan kepatuhan perpajakan sebagai salah satu topik riset utama yang dibutuhkan oleh Direktorat Jenderal Pajak. Penelitian ini penting dilakukan agar dapat memberikan gambaran yang luas tentang pola perkembangan perusahaan sektor makanan dan minuman yang melakukan tindakan penghindaran pajak. Tren penghindaran pajak ini akan membantu pemerintah khususnya Direktorat Jenderal Pajak untuk mengambil kebijakan dalam medeteksi perusahaan-perusahaan yang melakukan penghindaran pajak sehingga nantinya dapat menaikkan target penerimaan pajak dan meningkatkan tingkat kepatuhan wajib pajak. Penelitian ini juga dapat bermanfaat untuk pengembangan literature perpajakan khususnya tentang trend penghindaran pajak yang dilakukan oleh wajib pajak badan. 


\section{Agency Theory}

Teori agency (agency theory) yang dikemukakan oleh (Jensen \& Meckling, 1976) menjelaskan tentang hubungan antara prinsipal dalam hal ini adalah pemegang saham dan agen yang merupakan manajemen perusahaan. Aktivitas operasioanl perusahaan dijalankan oleh manajemen perusahaan dimana manajemen perusahaan berkewajiban mengelola sumber daya yang dimiliki dan berkewajiban juga mempertanggung jawabkan tugas yang dibebankan kepada mereka. Dalam prakteknya, hubungan antara pemegang saham (prinsipal) dan manajemen perusahan (agen) tidak selalu berjalan sesuai dengan yang diharapkan oleh kedua belah pihak sehingga menimbulkan asymmetry information, dimana terjadinya perbedaan kepentingan antara pemegang saham (prinsipal) dan manajemen perusahaan (agen). Pihak pemegang saham (prinsipal) menginginkan pembagian laba yang besar dan sesuai dengan kondisi yang sebenarnya sedangkan manajemen perusahaan (agen) menginginkan pembagian bonus yang besar dari prinsipal karena telah bekerja dengan baik. Kondisi ini akan memicu ketidaksesuaian keadaan yang sebenarnya dimana adanya perbedaan pelaporan antara laba komersil dan laba fiskal yang dapat menimbulkan konflik kepentingan (agency theory) bagi pihak manajer dalam melaporkan kinerja perusahaan. Manajer akan berusaha melaporkan laba yang lebih tinggi dalam laporan keuangan agar mendapatkan kompensasi atau bonus sehingga pihak manajemen akan melakukan perencanaan pajak dan dapat menimbulkan perilaku oportunistik untuk melakukan manifulasi laba yang tidak sesuai, aktivitas perusahaan pajak yang dilakukan oleh manajer dapat melalui tindakan penghindaran pajak (tax avoidance).
Tindakan penghindaran pajak yang dilakukan oleh pihak manajemen merupakan aktivitas yang menghasilkan informasi menyesatkan bagi pemegang saham dikarenakan pihak manajemen kurang transparan dalam menjalankan operasional perusahaan.

\section{Penghindaran Pajak}

Penghindaran pajak merupakan upaya yang legal dan aman bagi wajib pajak tanpa bertentangan dengan ketentuan perpajakan yang berlaku (Pohan, 2018). Penghindaran pajak dilakukan dengan metode dan teknik yang cendrung memanfaatkan kelemahan-kelemahan (grey area) yang terdapat dalam undang-undang dan peraturan untuk memperkecil jumlah pajak yang terutang. Praktek penghindaran pajak akan berdampak pada terkikisnya potensi penerimaan pajak oleh negera hal ini mengakibatkan ketidakadilan dan kurang efesiensi dari suatu system perpajakan. Penghindaran pajak umumnya dilakukan melalui skema-skema transaksi yang kompleks yang dirancang secara sistematis, penghindaran pajak dapat dilakukan oleh wajib pajak besar sampai wajib pajak biasa-biasa saja. Wajib pajak besar cenderung memanfaatkan kemampuan keuangannya yang besar untuk menyewa orang yang andal dan tahu celah-celah di dalam undang-undang perpajakan sedangkan wajib pajak biasa biasanya menahan untuk membeli, mempergunakan, bekerja pada sesuatu hal untuk menghindari pengenaan pajak. Menurut (Kurniawan, 2015) modus penghindaran pajak yang dilakukan oleh wajib pajak dapat berupa : Memperkecil penjualan; Memperbesar pembelian; Alokasi biaya administrasi dan umum (overhead cost); Pinjaman pemegang saham (shareholder loan); Pembayaran royalty; Pembayaran jasa inra group; Jasa produksi/maklon; Dummy company/letter box company; 
Reinvoicing; Penjualan atau pembelian saham. Penghindaran pajak dalam penelitian ini diukur dengan Effective Tax Rate (ETR) seperti yang dilakukan oleh (Desai \& Dharmapala, 2004) dan (Dyreng et al., 2008) proksi ETR merupakan perbandiangan antara beban pajak penghasilan badan dengan pendapatan sebelum pajak.

\section{Tren Penghindaran Pajak}

Penghindaran pajak merupakan salah satu bentuk tidakpatuhan wajib pajak dan merupakan bentuk perlawanan pajak yang dilakukan oleh wajib pajak ketika Surat Ketetapan Pajak belum dikeluarkan, tindakan penghindaran pajak ini belum diatur secara jelas di dalam undang-undang. Ada 2 karekateristik wajib pajak yang melakukan penghindaran pajak yaitu wajib pajak besar dan wajib biasa. Wajib pajak besar dapat melakukan tindakan penghindaran pajak dengan menyewa ahli hukum dan konsultan yang handal untuk mengetahui celah-celah dalam undang-undang perpajakan sedangkan wajib pajak biasa melakukan penghindaran pajak dengan menaham untuk membeli, mempergunakan, bekerja pada suatu hal untuk menghindari pajak baik PPN maupun pajak penghasilan. Fenomena penghindaran pajak tidak hanya dilakukan oleh wajib pajak Indonesia tetapi juga dijumpai di negara Amerika dimana hampir seperempat penduduk Amerika telah melakukan penghindaran pajak dengan membayar pajak kurang 20 persen padahal rata-rata pajak yang harus dibayarkan mendekati 30 persen (Dyreng et al., 2008). Berdasarkan fenomena ini maka perlu dilakukan penelitian tentang tren penghidaran pajak agar dapat menunjukkan kecendrungan perusahaanperusahaan dalam melakukan penghindaran pajak pada jangka waktu yang panjang. Trend ini dapat digunakan oleh Direktorat Jenderal Pajak peralaman kebijakan dan evaluasi kebijakan yang akan diputuskan sehingga kepatuhan wajib pajak dapat meningkat.

\section{METODE PENELITIAN}

Jenis penelitian ini adalah penelitian deskriptif, yaitu penelitian yang menjelaskan satu variable dalam situasi tertentu (Sekaran, 2006). Penelitian ini merupakan studi empiris yang dilakukan untuk membuktikan trend penghindaran pajak pada perusahaan makanan dan mimuman yang terdaftar di BEI dalam kurun waktu yang panjang (dengan tahun pengamaan 2011-2020/10 tahun). Populasi dalam penelitian ini adalah perusahaan makanan dan minuman yang terdaftar di Bursa Efek Indonesia (BEI) tahun 20211-2020 dengan populasi sebanyak 80 perusahaan. Teknik pengambilan sampel penelitian ini dilakukan dengan menggunakan teknik purposive sampling yaitu melalui pengambilan sampel secara khusus berdasarkan kriteria-kriteria tertentu. Adapun kriteria yang digunakan untuk memilih sampel adalah sebagai berikut:

a. Perusahaan makanan dan minuman yang terdaftar di Bursa Efek Indonesia (BEI) selama 10 tahun berturut-turut yaitu tahun 2011-2020, pemilihan periode penelitian ini dirasa cukup representatif untuk dijadikan data dalam penelitian ini.

b. Perusahaan makanan dan minuman yang tidak delisting (keluar) dan new listing di Bursa Efek Indonesia (BEI) selama 10 tahun berturut-turut yaitu tahun 2011-2020.

c. Perusahaan yang menerbitkan laporan keuangan periode 2011-2020

d. Perusahaan yang tidak mengalami kerugian selama periode penelitian 2011-2020 
Tabel 1

Hasil Pemilihan Sampel

\begin{tabular}{|c|c|c|}
\hline No & Keterangan & Jumlah \\
\hline \multicolumn{2}{|c|}{$\begin{array}{l}\text { Perusahaan makanan dan minuman yang } \\
\text { terdaftar di BEl tahun 2011-2020 }\end{array}$} & 32 \\
\hline 3 & $\begin{array}{l}\text { Perusahaan yang delisted } \\
\text { dan new listing selama } \\
2011-2020 \\
\text { Perusahaan yang tidak } \\
\text { menerbitkan laporan } \\
\text { keuangan } \\
\text { Perusahaan memiliki laba } \\
\text { negatif }\end{array}$ & $\begin{array}{l}(20) \\
(1) \\
(3)\end{array}$ \\
\hline Total pe & an yang memenuhi kreteria & 8 \\
\hline
\end{tabular}

Sumber data dalam penelitian ini adalah data sekunder yang merupakan sumber data penelitian yang diperoleh secara tidak langsung melalui media perantara. Variabel yang diteliti tersedia dengan lengkap pelaporan keuangan dan ringkasan kinerja tahun 2011-2020. Sumber data diperoleh dari website IDX : www.idx.co.id.

Untuk memperoleh data yang dibutuhkan dalam penelitian ini, penulis menggunakan teknik observasi dokumentasi dengan melihat laporan keuangan, laporan tahunan dan ringkasan kinerja perusahaan.

\section{Definisi Operasional Variabel}

Variabel dalam penelitian ini adalah penghindaran pajak (tax avoidance). Pengukuran tax avoidance sendiri menggunakan proksi dengan menggunakan proksi Effective Tax Rates (ETR) yang diharapkan mampu mengidentifikasi keagresifan perencanaan pajak perusahaan yang dilakukan menggunakan perbedaan tetap maupun perbedaan temporer (Chen et al., 2010) dengan rumus sebagai berikut:

$$
E T R=\frac{\text { Beban Pajak Penghasialan }}{\text { Pendapatan Sebelum Pajak }}
$$

\section{Definisi Operasional Variabel}

\begin{tabular}{c|c}
$\begin{array}{c}\text { Effective Tax Rates } \\
(\text { ETR })\end{array}$ & ETR $=\frac{\text { Beban Pajak Penghasialan }}{\text { Pendapatan Sebelum Pajak }}$ \\
\hline
\end{tabular}

\section{Teknik Analisis Data}

Teknik Analisis data dalam penelitian ini menggunakan pengujian statistik desktiptif digunakan untuk memberikan gambaran profil data sampel. Statistik deskriptif juga bermanfaat untuk mendeskripsikan variabel-variabel dalam penelitian ini, yaitu akan memberikan gambaran umum variabel penelitian. Statistik deskriptif yang digunakan antara lain: mean, standard deviation, maximal, minimal maupun tabel dan chart.

\section{HASIL DAN PEMBAHASAN}

Penelitian ini menggunakan seluruh perusahaan food and beverage (makanan dan minuman) yang terdaftar di Bursa Efek Indonesia (www.idx.co.id) sebagai objek penelitian dengan menggunakan motode purposive sampling sehingga dari 32 populasi penelitian diperoleh 8 perusahaan sebagai sampel penelitian ini, dimana ada 20 perusahaan yang new listing dan delisting sepanjang tahun 2011-2020, 1 perusahaan yang tidak menerbitkan laporan keuangan secara lengkap dan ada 3 perusahaan yang memiliki laba negatif sepanjang tahun 2011-2020 sehingga terdapat 8 perusahaan yang menjadi sampel dalam penelitian ini.

\section{Analisis Data}

Alat analisis yang digunakan dalam penelitian ini adalah Statistik Deskriptif yang diuraikan gambaran sebaran nilai dari variabel. Selanjutnya deskripsi dari variabel dijelaskan pada tabel dibawah ini:

\section{Tabel 2}

\section{Hasil Statistik Deskriptif}

\begin{tabular}{ccccccc}
\hline No & Tahun & Mean & Median & Max & Min & St.Dev \\
\hline $\mathbf{1}$ & 2011 & 0,17519 & 0,22907 & 0,25946 & 0,02104 & 0,10139 \\
$\mathbf{2}$ & 2012 & 0,22133 & 0,24410 & 0,25768 & 0,06522 & 0,06420 \\
$\mathbf{3}$ & 2013 & 0,20457 & 0,24885 & 0,29409 & 0,02535 & 0,10034 \\
$\mathbf{4}$ & 2014 & 0,20861 & 0,24691 & 0,29349 & 0,05567 & 0,08843 \\
$\mathbf{5}$ & 2015 & 0,22473 & 0,25118 & $\mathbf{0 , 3 4 8 7 2}$ & 0,04787 & 0,09798 \\
$\mathbf{6}$ & 2016 & 0,23831 & 0,24936 & 0,34295 & 0,07457 & 0,07548 \\
$\mathbf{7}$ & 2017 & 0,24933 & 0,26504 & 0,32819 & 0,01429 & 0,10025 \\
$\mathbf{8}$ & 2018 & 0,27753 & 0,26709 & 0,33371 & 0,23370 & 0,03302 \\
$\mathbf{9}$ & 2019 & 0,24300 & 0,25269 & 0,32536 & 0,04449 & 0,08756 \\
$\mathbf{1 0}$ & 2020 & 0,23330 & 0,25272 & 0,29659 & 0,05146 & 0,07954 \\
\hline
\end{tabular}




\begin{tabular}{|c|c|c|c|c|c|c|}
\hline No & Tahun & Mean & Median & Max & Min & St.Dev \\
\hline $\begin{array}{c}\text { Nilai } \\
\text { Rata2 }\end{array}$ & 0,2276 & & & & & \\
\hline
\end{tabular}

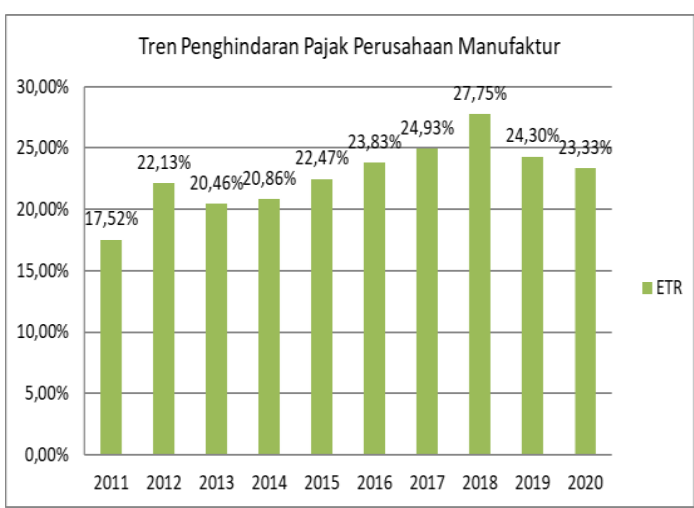

\section{Gambar 1}

\section{Tren Penghindaran Pajak}

Deskripsi statistik untuk proksi penghindaran pajak yaitu mean, median, nilai maksimum, nilai minimum dan standar deviasi dari nilai ETR. Semakin kecil nilai ETR maka semakin besar kemungkinan perusahaan tersebut untuk melakukan tindakan penghindaran pajak hal ini sesuai dengan penelitian yang dilakukan oleh (Nuritomo \& Martani, 2014). Penghitungan ETR ini bertujuan untuk melihat beban pajak yang dibayarkan dalam tahun pajak yang berjalan. Tabel 4 memperlihatkan nilai rata-rata ETR dalam kurun waktu 10 tahun sebesar $23 \%$ dan nilai maksimal ETR sepanjang 10 tahun (2011-2020) sebesar 34,87\% yaitu pada tahun 2015 . Hal ini mengindikasikan bahwa beban pajak yang dibayarkan oleh perusahaan makanan dan minuman kepada pemerintah sudah mencapai $34,87 \%$, semakin kecil nilai ETR mengindikasikan semakin besar kemunginanan perusahaan melakukan penghindaran pajak. Tahun 2016 pemerintah melalui PER 11/PJ/2016 tentang Pengaturan lebih lanjut mengenai Pelaksanaan Undang-Undang No.11 Tahun 2016 tentang Pengampunan Pajak, menetapkan kebijakan tax amnesty yang bertujuan untuk mempercepat pertumbuhan dan restrukturasi ekonomi, mendorong reformasi perpajakan menuju sistem perpajakan yang lebih memiliki keadilan, memperluas basis data perpajakan yang lebih valid, komprehensif dan terintegrasi sehingga tujuan untuk meningkatkan penerimaan pajak bagi pembiayaan pembangunan dapat tercapai. Kebijakan tax amnesty membuat potensi penerimaan APBN pada tahun bersangkutan dan tahun setelahnya bertambah, sehingga sangat membantu upaya pemerintah dalam memperbaiki kondisi perekonomian, pembangunan dan mengurangi pengangguran, mengurangi kemiskinan, serta memperbaiki ketimpangan. Kebijakan tax amnesty ini diharapkan diikuti repatriasi sebagian atau keseluruhan asset orang Indonesia diluar negeri yang sangat membantu stabilitas makro ekonomi yang dapat dilihat dari nilai tukar rupiah, cadangan devisa, neraca pembayara, dan likuiditas dari perbankan. Secara singkat, kebijakan tax amnesty sangat strategis karena berdampak makro menyeluruh dan fundamental bagi perekonomian Indonesia. Kebijakan tax amnesty tersebut dilakukan oleh pemerintah sampai dengan tahun 2018 hal ini terbukti dengan rendahnya tingkat penghindaran pajak yang dilakukan oleh perusahaan makanan dan minuman yang terdaftar di BEI secara rata-rata sebesar $27,75 \%$, hal ini dapat disimpulkan bahwa beban pajak yang dibayarkan kepada pemerintah sudah mencapai $27,75 \%$ yang terlihat pada gambar 1 .

Pemerintah melalui UU No. 36 Tahun 2008 Tentang Pajak Penghasilan (Indonesia, 2008) menetapkan tarif PPh Badan sebesar $25 \%$ yang efektif pada tahun 2010, dan 5\% lebih rendah dari tarif normal yang diterapkan kepada wajib pajak badan dalam negeri (WPDN) berbentuk perseroan terbuka dengan memenuhi syarat tertentu. Penurunan 
tarif pajak tahun 2010 memicu terbukanya celah praktek penghindaran pajak dimana wajib pajak badan memiliki ruang untuk mengecilkan penghasilan dengan memanfaatkan Pernyataan Standar Akuntansi Keuangan (PSAK 72), dimana perusahaan dapat menunda pengakuan pendapatan ke tahun berikutnya, khususnya untuk transaksi akhir tahun. Perusahaan melalui PSAK 72 ini dapat melakukan creative accounting untuk mengecilkan beban pajak mereka melalui praktek penghindaran pajak. Pemerintah sebenarnya memiliki dasar hukum yang kuat untuk meminimalisasi praktek penghindaran pajak yang mengacu pada PP No.94 Tahun 2020 Pasal 17 tentang Penghitungan Penghasilan Kena Pajak dan Pelunasan $\mathrm{PPh}$ dalam Tahun Berjalan. Aturan tersebut menetapkan saat pengakuan penghasilan dan biaya dalam hal-hal tertentu sesuai dengan kebijakan pemerintah. Peningkatan pendapatan kena pajak dapat dilihat dari pertumbuhan penjualan suatu perusahaan, semakin tinggi pertumbuhan penjualan perusahaan maka laba yang diperoleh diasumsikan juga semakin tinggi dan kinerja yang dimiliki perusahaan akan meningkat, dengan laba yang bertambah maka beban pajak yang dibayarkan kepada negara juga samakin besar sehingga perusahaan akan cendrung melakukan praktek penghindaran pajak hal ini sejalan dengan penelitian yang dilakukan oleh (Wahyuni et al., 2019). Hasil penelitian ini didukung dengan Teori agency (agency theory dimana pihak manajemen perusahaan sebagai agen akan mengoptimalkan penjualan sehingga laba yang diperoleh menjadi lebih besar dan disisi lain pihak menajemen juga akan melakukan perencanaan pajak agar beban yang harus dibayarkan menjadi lebih kecil hal ini dilakukan untuk mendapatkan kompensasi atau bonus sehingga dapat menimbulkan perilaku oportunistik untuk melakukan manifulasi laba yang tidak sesuai melalui tindakan penghindaran pajak (tax avoidance).

Pemerintah selain menerbitkan aturan-aturan diatas dalam meminimalisir terjadinya penghindaran pajak, pada tahun 2015 pemerintah juga mengeluarkan Keputusan Menteri Keuangan Nomor : 169/PMK.010/2015 tentang pembatasan DER (Debt to Equity Ratio) setinggi-tingginya $4: 1$. DER merupakan perbandingan total utang dan ekuitas (modal), penggunaan utang oleh perusahaan akan menimbulkan beban bunga yang dapat mengurangi Penghasilan Kena Pajak sehingga pemerintah melalui Peraturan Menteri Keuangan ini mencegah terjadinya pemberian deviden terselubung yang dilakukan oleh perusahaan yang berafiliasi dikarenakan peraturan ini memasukkan utang tanpa bunga kepada pemegang saham (yang memiliki hubungan istimewa) disebut dengan modal. Modal yang diperhitungkan dalam DER adalah modal yang dicatat sesuai dengan Standar Akuntansi Keuangan di Indonesia ditambah dengan pinjaman tanpa bunga dari pihak yang berafiliasi (memiliki hubungan istimewa). Wajib pajak memiliki kewajiban menyampaikan perhitungan DER dalam lampiran SPT Tahunan Pajak Penghasilan, ketentuan ini diatur pada pasal 7 Peraturan Direktur Jenderal Pajak Nomor PER-25/PJ/2017, dimana wajib pajak badan yang didirikan atau bertempat kedudukan di Indonesia, modalnya terbagi atas saham-saham, memiliki utang dan mengurangkan biaya pinjaman dalam penghitungan penghasilan kena pajak wajib menyampaikan laporan penghitungan besarnya perbandingan utang dan modal (DER) sebagai lampiran SPT Tahunan Pajak Penghasilan Wajib Pajak Badan jika dalam tersebut Wajib Pajak tidak 
menyampaikan laporan perhitungan DER dan tidak menggunakan format sesuai dengan PER-25/PJ/2017 maka SPT Tahunan Pajak Penghasilan Wajib Pajak Badan yang disampaikan dinyatakan tidak lengkap dan tidak sesuai dengan peraturan perpajakan yang berlaku di Indonesia. DER merupakan salah satu alat ukur thin capitalization, dengan DER yang tinggi umumnya perusahaan telah agresif dalam melakukan pembiayaan melalui utang, hal ini mengakibatkan berkurangnya laba dikarenakan bertambahnya beban bunga. Thin capitalization melalui DER dari sudut pandang kepentingan investor/kreditur merupakan bagian strategi pendanaan operasi perusahaan dengan memperbesar pijaman untuk meminimalkan pajak yang terutang. Thin capitalization dengan memperbesar utang merupakan upaya untuk mentransformasikan pembayaran kepada investor atas penghasilan deviden daripada penghasilan ekuitas karena terkena pemajakan ganda $(\mathrm{PPh}$ atas laba dan $\mathrm{PPh}$ atas deviden) dan untuk penghasilan dari bunga dari pinjaman hanya dikenakan sekali pemajakan. Praktek pembiayaan dengan utang lebih memberikan penghematan pajak dengan thin capitalization yang merupakan rekayasa pembentukan striktur modal dengan jumlah utang yang lebih besar daripada jumlah saham. Thin capitalization menjadi menarik dikarenakan adanya perbedaan dalam perlakukan pajak antara utang dan modal, dimana ketentuan perpajakan memperbolehkan pembayaran bunga atas pinjaman sebagai pengurag pajak sementara pembayaran deviden atas saham tidak dapat menjadi pengurang pajak. Perbedaan perlakukan bunga dan deviden dalam perpajakan menjadikan perusahaan melakukan penghindaran pajak melalui peningkatan beban bunga yang berdampak pada pengurangan jumlah pajak yang dibayar. Hal ini sejalan dengan penelitian yang dilakukan oleh (Rima \& Destriana, 2021) dan (Pitaloka \& Merkusiwati, 2019) yang menyakan bahwa adanya pengaruh antara leverage dan penghindaran pajak dikarenakan perusahaan yang memilih menggunakan kebijakan leverage akan mendapatkan insentif pajak dengan memanfaatkan beban bunga untuk memperkecil beban pajaknya. Kondisi ini menunjukkan perusahaan dengan tingkat leverage yang tinggi cenderung akan melakukan tindakan penghindaran pajak sebagai akibat dari insentif pajak atas beban bunga yang diterima perusahaan untuk meminimalkan beban pajaknya.

\section{SIMPULAN}

Penelitian ini bertujuan memberikan bukti secara empiris tentang trend penghidaran pajak di Indonesia dalam 10 tahun terakhir yang terjadi pada Perusahaan Manakanan dan Minuman yang terdaftar di Bursa Efek Indonesia, dari hasil penelitian ini maka dapat ditarik kesimpulan sebagai berikut:

1. Hasil penelitian memperlihatkan nilai rata-rata ETR dalam kurun waktu 10 tahun sebesar $23 \%$ dan nilai maksimal ETR sepanjang 10 tahun (2011-2020) sebesar $34,87 \%$ yaitu pada tahun 2015 . Hal ini mengindikasikan bahwa beban pajak yang dibayarkan oleh perusahaan makanan dan minuman kepada pemerintah sudah mencapai $34,87 \%$, semakin kecil nilai ETR mengindikasikan semakin besar kemunginanan perusahaan melakukan penghindaran pajak.

2. Pemerintah dalam upaya menurunkan tingkat penghindaran pajak yang dilakukan oleh wajib pajak sepanjang tahun 2011-2020 telah banyak mengeluarkan kebijakan-kebijakan seperti : penurunan tarif $\mathrm{PPh}$ badan pada tahun 2010 menjadi 25\%, Kebijakan tax amnesty yang dilakukan 
pemerintah dari tahun 2016-2018, dan mengeluarkan Keputusan Menteri Keuangan pada tahun 2015 Nomor : 169/PMK.010/2015 tentang pembatasan DER (Debt to Equity Ratio) setinggi-tingginya 4 : 1 guna untuk mencegah pemberian deviden terselubung.

3. Rekomendasi kepada peneliti selanjutnya yaitu dengan memperluas sampel penelitian menjadi seluruh sektor industri manufaktur lain yang terdaftar di BEI sehingga dapat diketahui gambaran penghindaran pajak untuk berbagai sub sektor industri dengan jangka waktu yang panjang.

\section{DAFTAR PUSTAKA}

Chen, S., Chen, X., Cheng, Q., \& Shevlin, T. (2010). Are family firms more tax aggressive than non-family firms? Journal of Financial Economics, 95(1), 41-61. https://doi.org/10.1016/j.jfineco.200 9.02.003

Darussalam, \& Septriadi, D. (2008). Konsep dan Aplikasi Cross-Border Transfer Pricing Untuk Tujuan Perpajakan (Darussalam \& D. Septriadi (eds.)). DANNY DARUSSALAM Tax Center.

Desai, M. a., \& Dharmapala, D. (2004). Corporate Tax Avoidance and High Powered Incentives. Journal of Financial Economics, April, 42. https://doi.org/10.2139/ssrn.532702

Dyreng, S. D., Hanlon, M., \& Maydew, E. L. (2008). Long-run corporate tax avoidance. Accounting Review, 83(1), 61-82. https://doi.org/10.2308/accr.2008.8 3.1.61

Indonesia， R. (2008). Undang-undang Republik Indonesia Nomor 36 tahun 2008 tentang Perubahan Keempat Atas Undang-Undang Nomor 7 tahun 1983 tentang Pajak
Penghasilan.

$1-188$.

https://www.pajak.go.id/sites/defaul t/files/2019-07/UU 36 2008.pdf

Kurniawan, A. M. (2015). Transfer Pricing untuk kepentingan pajak.pdf (Maya (ed.)). Andi Yogyakarta.

Nuritomo, \& Martani, D. (2014). Insentif Pajak, Kepemilikan dan Penghindaran Paja Perusahaan (Studi Penerapan Peraturan Pemerintah No.81 Tahun 2007). Simposium Nasional Akuntansi XVII.

Pitaloka, S., \& Merkusiwati, N. K. L. A. (2019). Pengaruh Profitabilitas, Leverage, Komite Audit, dan Karakter Eksekutif Terhadap Tax Avoidance. E-Jurnal Akuntansi Universitas Udayana, 27, 12021230.

Pohan, C. A. (2018). Optimizing Corporate Tax Management: Kajian Perpajakan dan Tax Planning (p. 630). Sina Grafika Offset.

Rima, lucy andreana, \& Destriana, N. (2021). Analisis penghindaran pajak dan faktor-faktor yang memengaruhinya. Trisakti School of Management, 1-11.

Santoso, Y. I. (2020). Dirjen Pajak Angkat Bicara Soal Kerugian Rp 68,7 Triliun Dari Penghindaran Pajak. Kontan.Co.Id, November. https://nasional.kontan.co.id/news/d irjen-pajak-angkat-bicara-soalkerugian-rp-687-triliun-daripenghindaran-pajak

Sekaran, U. (2006). Research Methods For Business (4th ed.). Salemba Empat.

Wahyuni, L., Fahada, R., \& Atmaja, B. (2019). The Effect of Business Strategy, Leverage, Profitability and Sales Growth on Tax Avoidance. Indonesian Management and Accounting Research, 16(2), 